\title{
L'alimentation : entre mondialisation et expression identitaire
}

Martine Garrigues-Cresswell et Marie Alexandrine Martin

\section{(2) OpenEdition}

Journals

Édition électronique

URL : https://journals.openedition.org/tc/373

DOI : $10.4000 /$ tc. 373

ISSN : 1952-420X

Éditeur

Éditions de l'EHESS

Édition imprimée

Date de publication : 1 avril 1999

ISSN : 0248-6016

Référence électronique

Martine Garrigues-Cresswell et Marie Alexandrine Martin, «L'alimentation : entre mondialisation et expression identitaire », Techniques \& Culture [En ligne], 31-32 | 1999, mis en ligne le 26 octobre 2005, consulté le 29 septembre 2022. URL : http://journals.openedition.org/tc/373 ; DOI : https://doi.org/ $10.4000 /$ tc. 373

Ce document a été généré automatiquement le 29 septembre 2022.

Tous droits réservés 


\section{L'alimentation : entre} mondialisation et expression identitaire

Martine Garrigues-Cresswell et Marie Alexandrine Martin 